\title{
Effect of Using Chemical Fertilizers on Natural Radioactivity Levels in Agricultural Soil in the Iraqi Kurdistan Region
}

\author{
Hiwa H. Azeez ${ }^{1 *}$, Habeeb Hanna Mansour ${ }^{1}$, Saddon T. Ahmad ${ }^{2}$ \\ ${ }^{1}$ Department of Physics, College of Education, Salahaddin University - Erbil, Iraq \\ ${ }^{2}$ School of Medicine, Koya University, Danielle Mitterrand Boulevard, Koya, Iraq
}

Received: 29 August 2018

Accepted: 28 March 2019

\begin{abstract}
In this study, the effect of the use of chemical fertilizers on natural radioactivity levels in agricultural soil was investigated. For this purpose, virgin and agricultural (fertilized) soils were collected from Erbil city, the capital of the Iraqi Kurdistan Region. Gamma-ray spectrometry was applied using a high-purity germanium (HPGe) detector to determine the activity concentrations of ${ }^{226} \mathrm{Ra},{ }^{232} \mathrm{Th}$, and ${ }^{40} \mathrm{~K}$ in soil samples. The results showed that the range of activity concentrations for ${ }^{226} \mathrm{Ra},{ }^{232} \mathrm{Th}$, and ${ }^{40} \mathrm{~K}$ in virgin soils are (10.6-16.2) $\mathrm{Bq} / \mathrm{kg}$, (8.8-10.7) $\mathrm{Bq} / \mathrm{kg}$, and (241.8-340.9) $\mathrm{Bq} / \mathrm{kg}$, respectively, while the range of activity concentrations for ${ }^{226} \mathrm{Ra},{ }^{232} \mathrm{Th}$, and ${ }^{40} \mathrm{~K}$ in agricultural soils are (11.9-18.2) $\mathrm{Bq} / \mathrm{kg},(8.8-12.4)$ $\mathrm{Bq} / \mathrm{kg}$, and (247.7-338.3) Bq/ $/ \mathrm{kg}$, respectively. The obtained values of activity concentration show that the application of chemical fertilizers elevated the natural radioactivity level of the soil. The radiological hazard parameters were also calculated in both the virgin and agricultural soil samples and compared with the international dose safety limit in the soil.
\end{abstract}

Keywords: radioactivity, soil, effective dose, fertilizer, hazard

\section{Introduction}

In recent years, studies of natural radioactive nuclides in the environment and their role in the organisms of our planet have attracted rising attention $[1,2]$. Also, natural radioactive materials have become of great interest in International Atomic Energy Agency (IAEA) publications and reports issued by the European Council Directive (EU) [2].
Natural radionuclides existing in the soil, water, and rocks are not distributed homogeneously throughout the world, but their concentrations depend mainly on geological and geographical conditions [3]. The natural radioactivity levels in soils have gained research interest because humans are exposed to natural radioactivity depending on the concentrations of these radioactive nuclides in each region of the world [4].

Information on radioactive nuclide distribution in soils is essential to the affected population and to control health risks [5]. The sources of radioactive nuclides are natural and artificial. The naturally occurring radioactive nuclides originate from ${ }^{238} \mathrm{U},{ }^{235} \mathrm{U}$, and ${ }^{232} \mathrm{Th}$ decay chains, and from ${ }^{40} \mathrm{~K}$, while artificial

*e-mail: hiwa.azeez@su.edu.krd 
sources come from various applications of radionuclides in industries, nuclear weapons tests, and consumer products [7].

The concentration of radioactive nuclides in soil increases by adsorption with soil and its rainfall on soil, while the concentration decreases via the process of leakage and also dilutes when soil water content and organic matter increases the behaviour of radioactive nuclides in soil regarding site characteristics, amount and rate of rainfall and soil drainage [8].

The natural radioactive nuclides in soil vary from one global region to another. In soil, one of the sources of radioactive materials other than those of natural origin is mainly due to the wide use of chemical fertilizers for agricultural purposes [9]. Chemical fertilizers are used by farmers in the agricultural fields to reach high agricultural productivity. The compounds commercially of chemical fertilizers are named NPK (nitrogen $(\mathrm{N})$, phosphorus $(\mathrm{P})$ and potassium $(\mathrm{K})$ ). The ${ }^{238} \mathrm{U}$ and ${ }^{232} \mathrm{Th}$ enrichment in chemical fertilizers are linked to the high concentration in phosphate rock and the complicated chemical process in fertilizer production. The primary source of phosphate fertilizer is phosphate rocks of sedimentary origin, which contain relatively high concentrations of ${ }^{238} \mathrm{U}$ and ${ }^{232} \mathrm{Th}$ and its decay products $[10,11]$. In NPK fertilizers, the potassium component increases the natural radioactivity, because of the presence of radioactive ${ }^{40} \mathrm{~K}$, whose natural abundance in potassium $(\mathrm{K})$ is $0.0118 \%$ [2].

Moreover, fertilizer materials such as phosphates (which contain ${ }^{238} \mathrm{U}$ and ${ }^{232} \mathrm{Th}$ ) and potassium, which are used in plant nitration processes, are considered to be important sources of soil contamination and become a source of radioactivity [11]. This phenomenon may result in potential radiological risks owing to external exposure during a resident time in the farms and internal exposure through ingestion of food grown on fertilizer soils. Using phosphate fertilizers over a period of many years could eventually increase the radium and uranium content of the soil and consequently increase radiation dose, which would result in the corresponding increase of the dose and cause diseases for the human body [12].

This study aims to assess the activity concentrations of ${ }^{226} \mathrm{Ra},{ }^{232} \mathrm{Th}$, and ${ }^{40} \mathrm{~K}$ in virgin and fertilized soils collected from fields in Erbil city, where a variety of chemical fertilizers are being used by farmers to enhance crop yield. In addition, the use of chemical fertilizers affects radioactivity levels in the agricultural soil. Comparison between the results obtained for virgin and fertilized soils are presented.

\section{Materials and Methods}

\section{Experimental Work}

The present study was carried out in agricultural fields in Erbil (the capital of Iraq's Kurdistan Region). Four different locations (which consist of four greenhouses and 11 agricultural fields) in Erbil were selected for collecting the soil samples to determine the activity concentrations of naturally occurring radioactive nuclides in virgin and fertilized soils. The geographical position of sampling locations is shown in Fig. 1.

The selection of the fields was such that it contained soils that had received different amounts of fertilizers for different intervals of time. The plant fertilizers urea $(\mathrm{N})$, diammonium phosphate (DAP), and urea ammonium phosphate (NP) were used by farmers in Ankawa, Binaslawa, and Bardarash locations to enhance the crop yield. Also, the plant fertilizers urea ammonium phosphate (NP), nitro phosphate potash mixed (NPK), calcium nitrate $(\mathrm{CaN})$, and potassium sulphate $(\mathrm{K})$ were used by farmers in the Yaremja (greenhouse and uncovered cultivate) location. In our previous work [8], the activity concentration of radioactive nuclides in

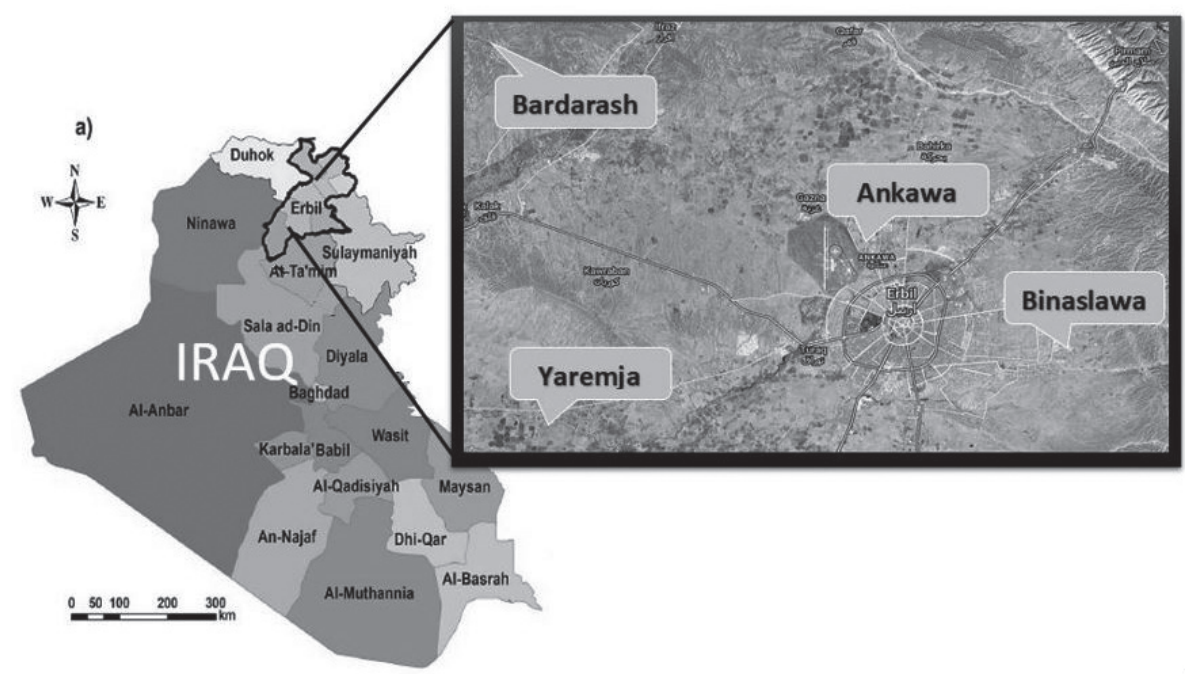

Fig. 1. Map of the studied area and sampling sites. 
Table 1. Chemical composition of plant fertilizer and activity concentrations of ${ }^{226} \mathrm{Ra},{ }^{232} \mathrm{Th}$, and ${ }^{40} \mathrm{~K}$ in Plant fertilizers used by the farmers in greenhouse and agricultural fields under study [11].

\begin{tabular}{|c|c|c|c|c|c|c|}
\hline \multirow{2}{*}{ Name of plant fertilizer } & \multicolumn{3}{|c|}{ Chemical analysis of fertilizers } & \multicolumn{3}{|c|}{ Activity concentration $(\mathrm{Bq} / \mathrm{Kg})$} \\
\cline { 2 - 7 } & $\mathrm{N} \%$ & $\mathrm{P}_{2} \mathrm{O}_{2} \%$ & $\mathrm{~K}_{2} \mathrm{O}$ & ${ }^{226} \mathrm{Ra}$ & ${ }^{232} \mathrm{Th}$ & ${ }^{40} \mathrm{~K}$ \\
\hline Potassium Sulfate (K) & 0 & 0 & 52 & $1.0 \pm 0.2$ & $0.2 \pm 0.02$ & $12000 \pm 600$ \\
\hline Urea (N) & 46 & 0 & 0 & $0.2 \pm 0.04$ & $0.2 \pm 0.03$ & $0.4 \pm 0.03$ \\
\hline Diammonium Phosphate (DAP) & 18 & 46 & 0 & $8.0 \pm 1.0$ & $1.5 \pm 0.1$ & $14 \pm 1$ \\
\hline Calcium Nitrate (16.5 \%Ca + N) & 13.5 & 0 & 0 & $2.0 \pm 0.2$ & $0.2 \pm 0.05$ & $1 \pm 0.2$ \\
\hline Urea Ammonium Phosphate (NP) (1) & 20 & 20 & 0 & $0.6 \pm 0.1$ & $4.0 \pm 0.2$ & $53 \pm 2$ \\
\hline Urea Ammonium Phosphate (NP) (2) & 18 & 44 & 0 & $0.4 \pm 0.13$ & $10.0 \pm 1.0$ & $4 \pm 0.5$ \\
\hline N.P.K. Complex (1) & 12 & 6 & 18 & $134.0 \pm 6.0$ & $1.0 \pm 0.2$ & $4000 \pm 200$ \\
\hline N.P.K. Complex (2) & 15 & 8 & 26 & $1.0 \pm 0.04$ & $0.2 \pm 0.04$ & $5000 \pm 250$ \\
\hline N.P.K. Complex (3) & 20 & 20 & 20 & $0.5 \pm 0.2$ & $1.0 \pm 0.3$ & $2400 \pm 120$ \\
\hline
\end{tabular}

these fertilizers was measured and analyzed, as shown in Table 1.

The soil samples were collected using a core method with a core of diameter $15 \mathrm{~cm}$ and a depth of $20 \mathrm{~cm}$. The depth of the soil is considered to be especially important when the distribution of radionuclides is inhomogeneous along the soil depth [13]. After removing stones and inorganic materials, the soil samples were dried in an electric oven at about $120^{\circ} \mathrm{C}$, before crushing and sieving through a $2 \mathrm{~mm}$ mesh sieve. One kilogram of each sample was packed in a Marinelli beaker (one-litre size) for gamma spectrometry system and closed for six weeks to establish secular equilibrium between the radium contents of the samples and its daughter radionuclides [14, 15].

\section{Data Acquisition}

In this study, the gamma spectrometry system with HPGe setup and a multichannel analyzer was used for counting the gamma-rays emitted from soil samples. The high-purity germanium detector is p-type of vertical closed-end coaxial, manufactured by PGT (Princeton Gamma-Tec PGT Company-USA) [16]. The system was calibrated for energy using three standard sources: ${ }^{60} \mathrm{Co}$, ${ }^{137} \mathrm{Cs}$, and ${ }^{226} \mathrm{Ra}$. The efficiency calibration was achieved using the same three standard sources. The detector was situated in a lead well with a thickness of $10 \mathrm{~cm}$ to shield the measuring station versus background radioactivity.

The samples were placed over the detector for at least 10 hours. The spectra were evaluated using a Thermo Scientific System 8000 multi-channel analyzer and the Quantum Gold 2001 computer software program from PGT Company-USA. In order to determine the background radiation in the cavity around the detector, an empty beaker was counted, loaded and tested for a measurement time of 10 hours. The background spectra were used to correct the net peak area of gamma rays of measured isotopes.

After the measurement and the subtraction of the background, the naturally occurring radioactive nuclides
${ }^{226} \mathrm{Ra},{ }^{232} \mathrm{Th}$, and ${ }^{40} \mathrm{~K}$ are considered in the spectrum analysis for the measured gamma-rays. The ${ }^{226} \mathrm{Ra}$ activity concentration was measured as the weighted average of the activity determined using the gamma-ray lines $351.9 \mathrm{keV}(35.8 \%)$ gamma-rays from ${ }^{214} \mathrm{~Pb}$ decay, $609.3 \mathrm{keV}$ (44.8\%), $1120 \mathrm{keV}(14.8 \%)$, and $1764.5 \mathrm{keV}$ (15.36\%) gamma-rays from ${ }^{214} \mathrm{Bi}$ decay. The activity concentration of ${ }^{232} \mathrm{Th}$, however, was measured as the weighted average of the activity determined using the gamma-ray lines $238.6 \mathrm{keV}(43 \%)$ from ${ }^{212} \mathrm{~Pb}$ decay, $583 \mathrm{keV}(84.5 \%)$ and $2614.5 \mathrm{keV}(99.16 \%)$ from ${ }^{208} \mathrm{Tl}$ decay, and $911.2 \mathrm{keV}(26.6 \%)$ from ${ }^{228} \mathrm{Ac}$ decay. Furthermore, the activity concentration of ${ }^{40} \mathrm{~K}$ was directly determined using the gamma-ray line at $1460.8 \mathrm{keV}(10.7 \%)$.

\section{Calculations}

\section{Activity Concentrations}

Activity concentrations of ${ }^{226} \mathrm{Ra},{ }^{232} \mathrm{Th}$, and ${ }^{40} \mathrm{~K}$ in soil samples were calculated using the following formula $[2,17]$ :

Activity concentration $=($ Net Count

$$
/(\varepsilon \times \mathrm{I \gamma} \times \mathrm{T} \times \mathrm{M})) \pm(\mathrm{SD} /(\varepsilon \times \mathrm{I \gamma} \times \mathrm{T} \times \mathrm{M}))
$$

...where $\varepsilon$ is the absolute gamma peak efficiency for the detector at a particular gamma-ray energy, $\mathrm{I}_{\gamma}$ is the decay intensity of the specific energy peak (including the decay branching ratio information), $\mathrm{T}$ is the counting time for the measurement in seconds, $\mathrm{M}$ is the mass of the sample in $\mathrm{kg}$, and SD is the standard deviation of the net count rate per second.

The percentage increase in activity concentrations of isotopes in agriculture soils was calculated using the following formula:

Percentage increase in activity concentration $(\mathrm{PIAC})=[(\mathrm{AA}-\mathrm{AV}) / \mathrm{AV}] \times 100 \%$ 
...where $A_{A}$ and $A_{V}$ are activity concentrations of the isotopes in agriculture and virgin soils, respectively.

\section{Radium Equivalent Activity ( $\left.R a_{e q}\right)$}

The distribution of natural radioactive nuclides in soils is not uniform. Therefore, the total exposure to radiation from ${ }^{226} \mathrm{Ra},{ }^{232} \mathrm{Th}$, and ${ }^{40} \mathrm{~K}$ nuclides was expressed by radium equivalent activity $\left(\mathrm{Ra}_{\mathrm{eq}}\right)$ in $(\mathrm{Bq} / \mathrm{kg})$. The radium equivalent activity in soil samples was calculated using the following formula $[18,19]$ :

$$
\mathrm{Ra}_{\mathrm{eq}}=\left(\mathrm{A}_{\mathrm{Ra}}\right)+\left(\mathrm{A}_{\mathrm{Th}} \times 1.43\right)+\left(\mathrm{A}_{\mathrm{K}} \times 0.077\right)
$$

...where $A_{\mathrm{Ra}}, \mathrm{A}_{\mathrm{Th}}$, and $\mathrm{A}_{\mathrm{K}}$ represent the activity concentrations of ${ }^{226} \mathrm{Ra},{ }^{232} \mathrm{Th}$, and ${ }^{40} \mathrm{~K}$ in a unit $(\mathrm{Bq} / \mathrm{kg})$, respectively. The safe value of $\mathrm{Ra}_{\mathrm{eq}}$ for any naturally occurring radioactive materials is reported by OECD 1979 to be less than $370 \mathrm{~Bq} / \mathrm{kg}$ [20, 21].

\section{Absorbed Gamma Dose Rates $\left(D_{R}\right)$}

The absorbed gamma dose rates in the air at $1 \mathrm{~m}$ above the ground surface for the uniform distribution of naturally occurring radionuclides were calculated based on guidelines provided by UNSCEAR [22].

$$
\begin{array}{r}
D_{\mathrm{R}}(\mathrm{nGy} / \mathrm{h})(\mathrm{NORM})=\left(\mathrm{A}_{\mathrm{Ra}} \times 0.462\right) \\
+\left(\mathrm{A}_{\mathrm{Th}} \times 0.604\right)+\left(\mathrm{A}_{\mathrm{K}} \times 0.0417\right)
\end{array}
$$

\section{Annual Effective Dose}

The annual effective dose (AED) was calculated from the absorbed gamma dose rates $\left(D_{R}\right)$ by using the dose conversion factor of $0.7 \mathrm{~Sv} / \mathrm{Gy}$ with an outdoor occupancy factor of 0.2 and 0.8 for indoor [22], and determined using the following equations $[5,23]$ :

$$
\operatorname{AED}(\mu \mathrm{Sv} / \text { year })=\mathrm{D}_{\mathrm{R}}(\mathrm{nGy} / \mathrm{h}) \times \mathrm{T} \times \mathrm{F}
$$

...where $\mathrm{D}_{\mathrm{R}}$ is the calculated dose rate (in $\mathrm{nGy} / \mathrm{h}$ ) and $\mathrm{T}$ is the occupancy time. $\mathrm{F}$ is the conversion factor - a value is published by UNSCEAR as $0.7 \mathrm{~Sv} / \mathrm{Gy}$ for environmental exposure to gamma rays of moderate energy [22, 24]. The outdoor occupancy factor $\mathrm{T}$ is about $(20 \%$ of $8760 \mathrm{~h}$ /year). The outdoor annual effective dose equivalent is given by the following equation:

$$
\begin{gathered}
\mathrm{AED}_{\text {outdoor }}(\mu \mathrm{Sv} / \text { year })=\mathrm{D}_{\mathrm{R}}(\mathrm{nGy} / \mathrm{h}) \times \\
(0.2 \times 8760 \mathrm{~h} / \text { year }) \times 0.7(\mathrm{~Sv} / \mathrm{Gy})
\end{gathered}
$$

\section{External Hazard Index $\left(H_{e x}\right)$}

The external hazard index $\left(\mathrm{H}_{\mathrm{ex}}\right)$ is an estimation of the hazard of the natural gamma radiation. $\mathrm{H}_{\mathrm{ex}}$ was determined by assuming that $370 \mathrm{~Bq} / \mathrm{kg}$ of ${ }^{226} \mathrm{Ra}$, $259 \mathrm{~Bq} / \mathrm{kg}$ of ${ }^{232} \mathrm{Th}$, and $4810 \mathrm{~Bq} / \mathrm{kg}$ of ${ }^{40} \mathrm{~K}$ are produced at the same gamma dose rate. In order to evaluate this index, we can use the following relationship $[5,25]$ :

$$
\begin{gathered}
\mathrm{H}_{\mathrm{ex}}=\left(\mathrm{A}_{\mathrm{Ra}} / 370\right)+\left(\mathrm{A}_{\mathrm{Th}} / 259\right) \\
+\left(\mathrm{A}_{\mathrm{K}} / 4810\right) \leq 1
\end{gathered}
$$

The external hazard index for ${ }^{226} \mathrm{Ra},{ }^{232} \mathrm{Th}$, and ${ }^{40} \mathrm{~K}$ nuclides is reported to be less than $1 \mathrm{mSv} /$ year, which relates to a radium equivalent activity of $370 \mathrm{~Bq} / \mathrm{kg}$ (OECD-1979) [20].

\section{Excess Lifetime Cancer Risk (ELCR)}

Excess lifetime cancer risk measures the additional cancer risk induced by exposure to ionizing radiations. Based on the calculated values of AED, ELCR is calculated using equation $[26,27]$ :

$$
\begin{aligned}
\mathrm{ELCR}_{\text {outdoor }} & =\mathrm{AED}_{\text {outdoor }}(\mu \mathrm{Sv} / \text { year }) \\
& \times \mathrm{DL} \times \mathrm{RF}
\end{aligned}
$$

...where AED is the annual effective dose, DL is the average duration of life ( 70 years), and $\mathrm{Rf}$ is the risk factor given as 0.05 by ICRP [28].

\section{Results and Discussion}

\section{Activity Concentrations of Radioactive Nuclides}

To assess the effect of the use of chemical fertilizers on the radioactivity levels in agricultural soils from Erbil governorate farms, the activity concentrations of natural radioactive nuclides ${ }^{226} \mathrm{Ra},{ }^{232} \mathrm{Th}$, and ${ }^{40} \mathrm{~K}$ in virgin and agricultural soils samples were measured using a gamma-ray spectrometer equipped with a highpurity germanium (HPGe) detector (Table 2).

The results showed that the mean values and the ranges of activity concentrations of ${ }^{226} \mathrm{Ra},{ }^{232} \mathrm{Th}$, and ${ }^{40} \mathrm{~K}$ in virgin soils are $14.3 \pm 2.2(10.6-16.2) \mathrm{Bq} / \mathrm{kg}$, $10.0 \pm \quad 0.8 \quad(8.8-10.7) \quad \mathrm{Bq} / \mathrm{kg}$, and 290.2 \pm 36.6 (241.8-340.9) $\mathrm{Bq} / \mathrm{kg}$, respectively. While the mean values and the ranges of activity concentrations of ${ }^{226} \mathrm{Ra},{ }^{232} \mathrm{Th}$, and ${ }^{40} \mathrm{~K}$ in agricultural soils are $16.0 \pm 1.8$ (11.9-18.2) Bq/kg, $10.3 \pm 1.1$ (8.8-12.4) Bq $/ \mathrm{kg}$, and $294.6 \pm 31.5(247.7-338.3) \mathrm{Bq} / \mathrm{kg}$, respectively. The variations in the activity concentrations of naturally occurring radioactivity nuclides in the soils in various locations in the studied area depend on the geological and geographical conditions in the area, as well as on the extent of fertilizer applied to agricultural lands because agricultural soils in the studied area had received different amounts of fertilizers for different intervals of time.

Fig. 2 shows the activity concentrations of ${ }^{226} \mathrm{Ra}$ and ${ }^{232} \mathrm{Th}$ in virgin and agricultural soils samples. Clearly, the fertilized soil samples are slightly more radioactive 
Table 2. Activity concentrations of ${ }^{226} \mathrm{Ra}$ and ${ }^{232} \mathrm{Th}$ in virgin and agricultural soil samples.

\begin{tabular}{|c|c|c|c|c|c|}
\hline \multirow{2}{*}{ Location } & \multirow{2}{*}{$\begin{array}{l}\text { Code of } \\
\text { Samples }\end{array}$} & \multirow{2}{*}{ Location } & \multicolumn{3}{|c|}{ Activity concentration $(\mathrm{Bq} / \mathrm{Kg})$} \\
\hline & & & ${ }^{226} \mathrm{Ra}$ & ${ }^{232} \mathrm{Th}$ & ${ }^{40} \mathrm{~K}$ \\
\hline \multirow{4}{*}{ Yaremja 1 (Green house) } & SV 1 & Virgin Soil & $14.8 \pm 0.7$ & $8.8 \pm 0.5$ & $241.8 \pm 12.8$ \\
\hline & SA 2 & Soil from Agricultural field 1 & $16.7 \pm 0.8$ & $8.8 \pm 0.5$ & $262.6 \pm 15.6$ \\
\hline & SA 3 & Soil from Agricultural field 2 & $15.1 \pm 0.6$ & $9.2 \pm 0.5$ & $274.3 \pm 16.8$ \\
\hline & SA 4 & Soil from Agricultural field 3 & $15.0 \pm 0.7$ & $8.8 \pm 0.4$ & $247.7 \pm 13.1$ \\
\hline \multirow{5}{*}{$\begin{array}{c}\text { Yaremja } 2 \\
\text { (uncovered cultivate) }\end{array}$} & SV 5 & Virgin Soil & $14.8 \pm 0.7$ & $10.6 \pm 0.6$ & $300.8 \pm 15.9$ \\
\hline & SA 6 & Soil from Agricultural field 4 & $17.9 \pm 0.8$ & $10.9 \pm 0.6$ & $311.2 \pm 16.4$ \\
\hline & SA 7 & Soil from Agricultural field 5 & $16.3 \pm 0.8$ & $10.7 \pm 0.3$ & $336.5 \pm 17.7$ \\
\hline & SA 8 & Soil from Agricultural field 6 & $18.2 \pm 0.8$ & $12.4 \pm 0.7$ & $335.8 \pm 18.0$ \\
\hline & SA 9 & Soil from Agricultural field 7 & $15.0 \pm 0.7$ & $10.9 \pm 0.6$ & $306.2 \pm 16.1$ \\
\hline \multirow{2}{*}{ Ankawa } & SV 10 & Virgin Soil & $16.2 \pm 0.6$ & $10.7 \pm 0.5$ & $295.0 \pm 15.4$ \\
\hline & SA 11 & Soil from Agricultural field 8 & $17.0 \pm 0.8$ & $10.9 \pm 0.6$ & $286.0 \pm 15.1$ \\
\hline \multirow{3}{*}{ Binaslawa } & SV 12 & Virgin Soil & $15.3 \pm 0.5$ & $10.2 \pm 0.4$ & $272.5 \pm 14.2$ \\
\hline & SA 13 & Soil from Agricultural field 9 & $15.3 \pm 0.6$ & $10.4 \pm 0.5$ & $272.1 \pm 14.3$ \\
\hline & SA 14 & Soil from Agricultural field 10 & $16.6 \pm 0.6$ & $10.3 \pm 0.5$ & $264.2 \pm 13.8$ \\
\hline \multirow{2}{*}{ Bardarash } & SV 15 & Virgin Soil & $10.6 \pm 0.3$ & $9.8 \pm 0.5$ & $340.9 \pm 18.3$ \\
\hline & SA 16 & Soil for Agricultural field 11 & $11.9 \pm 0.6$ & $10 \pm 0.5$ & $338.3 \pm 17.6$ \\
\hline
\end{tabular}

in comparison with the soil samples in which no fertilizer was used (virgin soil) for Ankawa, Bardarash, and Bnaslawa locations, while for Yaremja location (in both greenhouses and uncovered cultivated fields) the variation is more clear because in this location different types of chemical fertilizers such as potassium sulfate $(\mathrm{K})$, urea ammonium super phosphate (NP), and nitro phosphate potash mixed (NPK) fertilizer were used for different intervals of time. These chemical fertilizers, especially phosphate fertilizers, are enriched by ${ }^{226} \mathrm{Ra}$

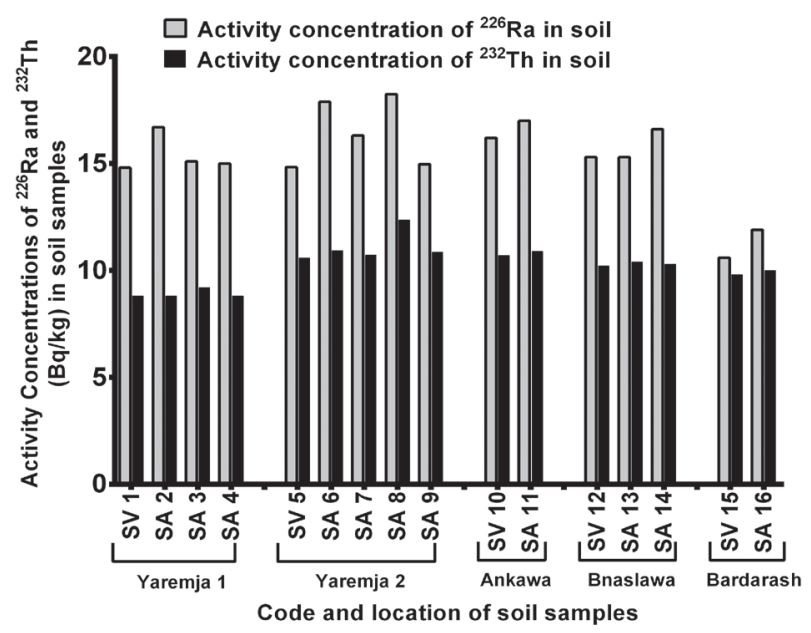

Fig. 2. Activity concentrations of ${ }^{226} \mathrm{Ra}$ and ${ }^{232} \mathrm{Th}$ in virgin (SV) and agricultural (SA) soil samples. and ${ }^{232} \mathrm{Th}$, and its decay products are linked to the high concentration in phosphate rock and the chemical process involved in fertilizer production, as shown in Table 1.

Fig. 3 shows the activity concentration of ${ }^{40} \mathrm{~K}$ in virgin and agricultural soil samples. In this figure, it is clear that the activity concentration of ${ }^{40} \mathrm{~K}$ in the fertilized soil samples collected from agricultural fields in Yaremja (in both greenhouses and uncovered cultivated fields) is higher than the soil samples in which

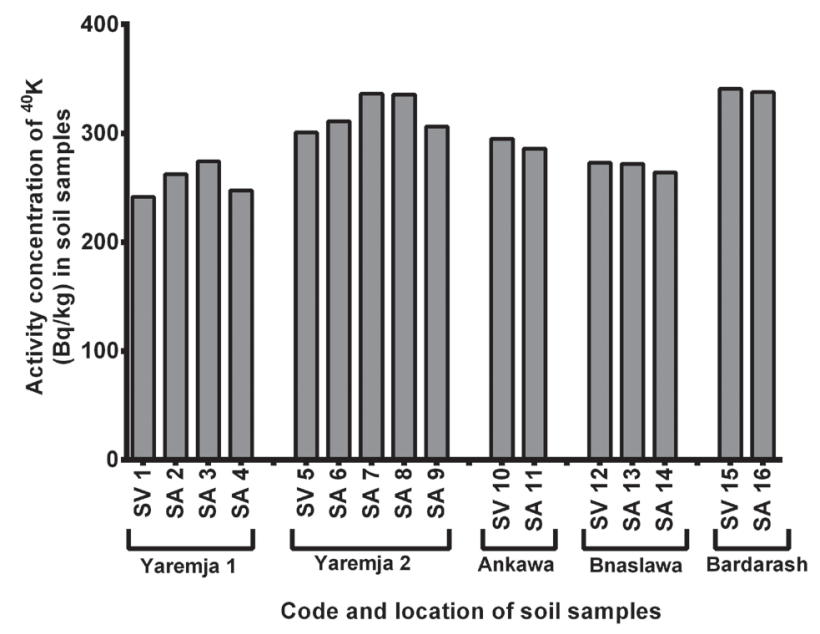

Fig. 3. Activity concentration of ${ }^{40} \mathrm{~K}$ in virgin (SV) and agricultural (SA) soil samples. 
Table 3. Percentage ratio of increase in activity concentrations of ${ }^{226} \mathrm{Ra},{ }^{232} \mathrm{Th}$, and ${ }^{40} \mathrm{~K}$ in agricultural soil samples due to the use of chemical fertilizers in this field.

\begin{tabular}{|c|c|c|c|c|c|}
\hline \multirow{2}{*}{ Location } & \multirow{2}{*}{ Code of Samples } & \multirow{2}{*}{ Location } & \multicolumn{3}{|c|}{ Increasing in the activity concentration $\%$} \\
\hline & & & ${ }^{226} \mathrm{Ra}$ & ${ }^{232} \mathrm{Th}$ & ${ }^{40} \mathrm{~K}$ \\
\hline \multirow{4}{*}{$\begin{array}{c}\text { Yaremja } \\
1 \text { (Green } \\
\text { house) }\end{array}$} & SV 1 & Virgin Soil & & & \\
\hline & SA 2 & Soil from Agricultural field 1 & 12.5 & 0.2 & 8.6 \\
\hline & SA 3 & Soil from Agricultural field 2 & 1.6 & 4.5 & 13.4 \\
\hline & SA 4 & Soil from Agricultural field 3 & 1.2 & 0.2 & 2.4 \\
\hline \multirow{5}{*}{$\begin{array}{c}\text { Yaremja } 2 \\
\text { (uncovered } \\
\text { cultivate) }\end{array}$} & SV 5 & Virgin Soil & & & \\
\hline & SA 6 & Soil from Agricultural field 4 & 20.6 & 3.2 & 3.5 \\
\hline & SA 7 & Soil from Agricultural field 5 & 10.1 & 1.4 & 11.9 \\
\hline & SA 8 & Soil from Agricultural field 6 & 23.0 & 16.9 & 11.6 \\
\hline & SA 9 & Soil from Agricultural field 7 & 1.4 & 2.6 & 1.8 \\
\hline \multirow{2}{*}{ Ankawa } & SV 10 & Virgin Soil & & & \\
\hline & SA 11 & Soil from Agricultural field 8 & 5.3 & 1.9 & 0 \\
\hline \multirow{3}{*}{ Binaslawa } & SV 12 & Virgin Soil & & & \\
\hline & SA 13 & Soil from Agricultural field 9 & 0.5 & 1.9 & 0 \\
\hline & SA 14 & Soil from Agricultural field 10 & 8.9 & 1.1 & 0 \\
\hline \multirow{2}{*}{ Bardarash } & SV 15 & Virgin Soil & & & \\
\hline & SA 16 & Soil for Agricultural field 11 & 12.8 & 1.9 & 0 \\
\hline
\end{tabular}

Table 4. Activity concentrations of naturally occurring radioactive nuclides in virgin and agriculture soils in the present work are compared with results reported from other countries throughout the world.

\begin{tabular}{|c|c|c|c|c|c|c|c|}
\hline \multirow{2}{*}{ Country } & \multicolumn{3}{|c|}{$\begin{array}{l}\text { Activity concentration of NORM in } \\
\text { virgin soil }(\mathrm{Bq} / \mathrm{kg})\end{array}$} & \multicolumn{3}{|c|}{$\begin{array}{l}\text { Activity concentration of NORM in } \\
\text { agriculture soil }(\mathrm{Bq} / \mathrm{kg})\end{array}$} & \multirow{2}{*}{ References } \\
\hline & ${ }^{226} \mathrm{Ra}$ & ${ }^{232} \mathrm{Th}$ & ${ }^{40} \mathrm{~K}$ & ${ }^{226} \mathrm{Ra}$ & ${ }^{232} \mathrm{Th}$ & ${ }^{40} \mathrm{~K}$ & \\
\hline Brazil & & & & $3-21$ & $0.4-17$ & $31-124$ & {$[30]$} \\
\hline Italy & & & & $24-231$ & $20-70$ & $242-1434$ & {$[31]$} \\
\hline Greece & & & & $8-68$ & $8-78$ & $185-868$ & {$[32]$} \\
\hline Algeria & 47 & 33 & 329 & 53 & 50 & 311 & [8] \\
\hline Egypt & & & & $2-14$ & $2-14$ & $54-170$ & {$[33]$} \\
\hline Pakistan & & & & $30-50$ & $42-56$ & 591-709 & {$[34]$} \\
\hline Malaysia & $45-111$ & $52-127$ & $99-173$ & $59-167$ & $88-181$ & $202-529$ & {$[5]$} \\
\hline India & $3-16$ & $37-299$ & $338-544$ & $3-21$ & $48-309$ & $322-564$ & [29] \\
\hline China & $9-145$ & $15-102$ & $417-1263$ & & & & {$[35]$} \\
\hline KSA & & & & $10-19$ & $9-28$ & $542-773$ & {$[6]$} \\
\hline Turkey & $13-31$ & $12-37$ & $285-614$ & & & & {$[36]$} \\
\hline Turkey & & & & $60-98$ & $55-81$ & $450-737$ & {$[37]$} \\
\hline Iran & 20 & 23 & 613 & $29-38$ & $26-34$ & $630-816$ & {$[38]$} \\
\hline Iraq & $16-39$ & $9-28$ & $262-613$ & & & & [39] \\
\hline Iraq & $11-16$ & $9-11$ & $242-341$ & $12-18$ & $9-12$ & $248-338$ & Present work \\
\hline Range in worldwide & $16-110$ & $11-64$ & $140-850$ & $16-110$ & $11-64$ & $140-850$ & {$[22]$} \\
\hline Worldwide average & 35 & 30 & 400 & 35 & 30 & 400 & {$[22]$} \\
\hline
\end{tabular}


Table 5. Radium equivalent activity $\left(\mathrm{Ra}_{\mathrm{eq}}\right)$, external absorbed gamma dose rates $\left(\mathrm{D}_{\mathrm{R}}\right)$, outdoor annual effective dose (AED), external hazard index $\left(\mathrm{H}_{\mathrm{ex}}\right)$, and excess lifetime cancer risk (ELCR) for virgin and agricultural soil.

\begin{tabular}{|c|c|c|c|c|c|c|c|}
\hline Location & $\begin{array}{l}\text { Code of } \\
\text { Samples }\end{array}$ & Location & $\begin{array}{c}\mathrm{Ra}_{\mathrm{eq}} \\
(\mathrm{Bq} / \mathrm{kg})\end{array}$ & $\begin{array}{c}\mathrm{D}_{\mathrm{R}} \\
\text { (nGy./h) }\end{array}$ & $\begin{array}{c}\text { AED } \\
(\mu \mathrm{Sv} / \text { year })\end{array}$ & $\begin{array}{c}\text { H ex } \\
(\mathrm{mSv} / \text { year })\end{array}$ & $\begin{array}{l}\text { (ELCR) } \\
\text { outdoor }\end{array}$ \\
\hline \multirow{4}{*}{$\begin{array}{c}\text { Yaremja } \\
1 \text { (Green } \\
\text { house) }\end{array}$} & SV 1 & Virgin Soil & $46.0 \pm 2.4$ & $22.2 \pm 1.2$ & $27.3 \pm 1.4$ & $0.12 \pm 0.01$ & $9.5 \mathrm{E}-5$ \\
\hline & SA 2 & Soil from Agricultural field 1 & $49.5 \pm 2.7$ & $24.0 \pm 1.3$ & $29.4 \pm 1.6$ & $0.13 \pm 0.01$ & $1.0 \mathrm{E}-4$ \\
\hline & SA 3 & Soil from Agricultural field 2 & $49.3 \pm 2.7$ & $23.9 \pm 1.3$ & $29.3 \pm 1.6$ & $0.13 \pm 0.01$ & $1.0 \mathrm{E}-4$ \\
\hline & SA 4 & Soil from Agricultural field 3 & $46.7 \pm 2.3$ & $22.6 \pm 1.1$ & $27.7 \pm 1.4$ & $0.12 \pm 0.01$ & 9.7 E-5 \\
\hline \multirow{5}{*}{$\begin{array}{c}\text { Yaremja } 2 \\
\text { (uncovered } \\
\text { cultivate) }\end{array}$} & SV 5 & Virgin Soil & $53.1 \pm 2.7$ & $25.8 \pm 1.3$ & $31.6 \pm 1.6$ & $0.14 \pm 0.01$ & $1.1 \mathrm{E}-4$ \\
\hline & SA 6 & Soil from Agricultural field 4 & $57.5 \pm 2.9$ & $27.8 \pm 1.4$ & $34.1 \pm 1.7$ & $0.16 \pm 0.02$ & $1.2 \mathrm{E}-4$ \\
\hline & SA 7 & Soil from Agricultural field 5 & $57.6 \pm 2.6$ & $28.0 \pm 1.3$ & $34.4 \pm 1.6$ & $0.16 \pm 0.02$ & $1.2 \mathrm{E}-4$ \\
\hline & SA 8 & Soil from Agricultural field 6 & $61.8 \pm 3.1$ & $29.9 \pm 1.5$ & $36.7 \pm 1.9$ & $0.17 \pm 0.03$ & $1.3 \mathrm{E}-4$ \\
\hline & SA 9 & Soil from Agricultural field 7 & $54.1 \pm 2.8$ & $26.2 \pm 1.3$ & $32.2 \pm 1.7$ & $0.15 \pm 0.02$ & $1.1 \mathrm{E}-4$ \\
\hline \multirow{2}{*}{ Ankawa } & SV 10 & Virgin Soil & $54.3 \pm 2.6$ & $26.3 \pm 1.2$ & $32.2 \pm 1.5$ & $0.15 \pm 0.03$ & $1.1 \mathrm{E}-4$ \\
\hline & SA 11 & Soil from Agricultural field 8 & $54.6 \pm 2.8$ & $26.4 \pm 1.3$ & $32.3 \pm 1.6$ & $0.15 \pm 0.01$ & $1.1 \mathrm{E}-4$ \\
\hline \multirow{3}{*}{ Binaslawa } & SV 12 & Virgin Soil & $50.9 \pm 2.1$ & $24.6 \pm 1.0$ & $30.2 \pm 1.3$ & $0.14 \pm 0.01$ & $1.1 \mathrm{E}-4$ \\
\hline & SA 13 & Soil from Agricultural field 9 & $51.2 \pm 2.4$ & $24.7 \pm 1.2$ & $30.3 \pm 1.4$ & $0.14 \pm 0.01$ & $1.1 \mathrm{E}-4$ \\
\hline & SA 14 & Soil from Agricultural field 10 & $51.8 \pm 2.4$ & $24.9 \pm 1.2$ & $30.6 \pm 1.4$ & $0.14 \pm 0.02$ & $1.1 \mathrm{E}-4$ \\
\hline \multirow{2}{*}{ Bardarash } & SV 15 & Virgin Soil & $50.9 \pm 2.5$ & $25.0 \pm 1.2$ & $30.7 \pm 1.5$ & $0.14 \pm 0.02$ & $1.1 \mathrm{E}-4$ \\
\hline & SA 16 & Soil for Agricultural field 11 & $52.3 \pm 2.7$ & $25.7 \pm 1.3$ & $31.5 \pm 1.6$ & $0.14 \pm 0.03$ & $1.1 \mathrm{E}-4$ \\
\hline \multicolumn{3}{|c|}{ Average } & $52.9 \pm 4.1$ & $25.6 \pm 2.0$ & $31.5 \pm 2.4$ & $0.14 \pm 0.02$ & $1.1 \mathrm{E}-4$ \\
\hline
\end{tabular}

no fertilizer was used (virgin soil), because in these locations potassium content fertilizers such as potassium sulfate (K) and nitro phosphate potash mixed (NPK) fertilizer were used to enhance the crop yield, which are rich in potassium radioactive isotope ${ }^{40} \mathrm{~K}$. On the other hand, a comparison of the virgin and fertilized soils of the Ankawa, Binaslawa, and Bardarash locations reveals that there is no increase in the activity concentrations of ${ }^{40} \mathrm{~K}$ in both types of soils because, as shown in Table 1, the fertilizers used in these areas were urea, urea ammonium phosphate (NP), and diammonium phosphate (DAP); there is no potassium content in these fertilizers.

Table 3 shows an increase in activity concentration percentage ratios of ${ }^{226} \mathrm{Ra},{ }^{232} \mathrm{Th}$, and ${ }^{40} \mathrm{~K}$ in agricultural soil samples due to the use of chemical fertilizers in these fields. The data shows that the use of chemical fertilizers in the studied area has elevated the activity concentrations of ${ }^{226} \mathrm{Ra},{ }^{232} \mathrm{Th}$, and ${ }^{40} \mathrm{~K}$ by factors of $0.5-23 \%, 0.2-16.9 \%$, and $0-13.4 \%$, respectively.

The obtained values of activity concentrations of naturally occurring radioactive nuclides in both virgin and agricultural soil samples were within the world average values of 35,30 , and $400 \mathrm{~Bq} / \mathrm{kg}$ for ${ }^{226} \mathrm{Ra},{ }^{232} \mathrm{Th}$, and ${ }^{40} \mathrm{~K}$, respectively [22]. Activity concentrations of ${ }^{226} \mathrm{Ra},{ }^{232} \mathrm{Th}$, and ${ }^{40} \mathrm{~K}$ in soil samples from the area under study are compared with results reported from other countries throughout the world (Table 4).

\section{Radiological Hazard Assessment}

In order to estimate the radiological hazards, we calculated the radium equivalent activity $\left(\mathrm{Ra}_{\mathrm{eq}}\right)$, external hazard index $\left(\mathrm{H}_{\mathrm{ex}}\right)$, external absorbed gamma doses rate $\left(D_{R}\right)$, outdoor annual effective dose (AED) ${ }_{\text {outdoor' }}$, and excess lifetime cancer risk (ELCR) for virgin and agricultural soil samples (Table 5).

The calculated radium equivalent activity $(\mathrm{Ra})$ in virgin soil samples varied from (46.0-54.3) $\mathrm{Bq} / \mathrm{kg}$, and in agricultural soil samples varied from (46.7-61.8) Bq/kg, with the average value $(52.9 \pm 4.1 \mathrm{~Bq} / \mathrm{kg})$. Variations in the radium equivalent activity in different soil samples depended on the type and content of natural radioactive nuclide as well as the type of chemical fertilizer used in the studied area. In Fig. 4, it is clear that the radium equivalent activity in the virgin soil sample is lower than the soil samples collected from agricultural fields where fertilizers are used. Thus the use of chemical fertilizers in the fields to enhance crop yield promotes the radium equivalent activity, and therefore the exposure of the farmers working in these fields. The obtained values of radium equivalent activity in soil samples are within the recommended limits of $370 \mathrm{~Bq} / \mathrm{kg}$ [20, 21, 29].

The absorbed gamma dose rates $\left(D_{R}\right)$ were calculated to vary from (22.2-26.3) $\mathrm{nGy} / \mathrm{h}$ in virgin soil samples, while in soil samples collected from agricultural fields 


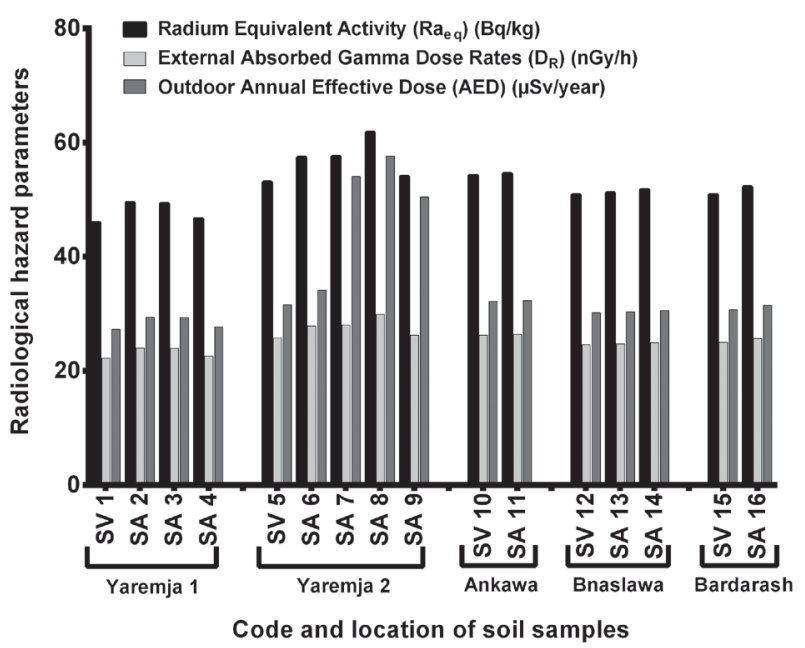

Fig. 4. Radium equivalent activity $\left(\mathrm{Ra}_{\mathrm{eq}}\right)$, external absorbed gamma dose rates $\left(D_{R}\right)$, and outdoor annual effective dose (AED) in virgin (SV) and agricultural (SA) soil samples under study.

vary from (22.6-29.9) $\mathrm{nGy} / \mathrm{h}$, with an average value of $25.6 \pm 2.0 \mathrm{nG} / \mathrm{h}$. The calculated average value of the absorbed gamma dose rates $\left(D_{R}\right)$ was lower than the worldwide average value of $59 \mathrm{nGy} / \mathrm{h}$ as published by UNSCEAR [22].

The calculated outdoor annual effective dose $\left(\mathrm{AEDE}_{\text {outdoor }}\right)$ in virgin soil samples varied from (27.3-32.2) $\mu \mathrm{Sv} / \mathrm{year}$, and in agricultural soil samples varied from (27.7-36.7) $\mu \mathrm{Sv} / \mathrm{year}$, with the average value (31.5 $2.4 \mu \mathrm{Sv} /$ year). The annual effective dose values are within the worldwide average value of $70 \mu \mathrm{Sv} /$ year, as published by UNSCEAR [22]. As shown in Fig. 4, the calculated absorbed gamma dose rates and annual effective dose equivalent for the soil samples in which fertilizers were used are higher than the virgin soil samples.

The external hazard index ranges for virgin and agricultural soil samples were $(0.12-0.15) \mathrm{mSv} /$ year, and $(0.12-0.17) \mathrm{mSv} /$ year, respectively. The calculated external hazard index for the soil samples in which fertilizers were used are higher than the virgin soil samples only in Yaremja (in both fields greenhouses and uncovered cultivate), because in these fields different types of chemical fertilizers (such as potassium sulfate $(\mathrm{K})$, urea ammonium super phosphate (NP), and nitro phosphate potash mixed (NPK) fertilizer) were used, while there is no change observed in values of external hazard index for both virgin and agricultural soil samples in Ankawa, Binaslawa, and Bardarash, where chemical fertilizers urea, diammonium phosphate, and urea ammonium phosphate were used in these fields to enhance the crop yield. The external hazard index for the soil samples in the studied area is lower than the safety limit of $1 \mathrm{mSv} /$ year as recommended by the OECD [20, 29].

The calculated excess lifetime cancer risk (ELCR ${ }_{\text {outdoor }}$ ) values for virgin and agricultural soil samples are $\left(9.5 \times 10^{-5}-1.1 \times 10^{-4}\right)$, and $\left(9.7 \times 10^{-5}-1.3\right.$ $\left.\mathrm{x} 10^{-4}\right)$, resepectivily. From the comparison of the values of excess lifetime cancer risk for virgin and agricultural soil samples of the investigated region, there is no drastic change in the excess lifetime cancer risk in both types of soils.

The results of the present study indicate that the use of chemical fertilizers in agriculture fields to enhance crop yield increases the activity concentrations of natural radioactive nuclides and therefore the exposure of the farmers working in the fields, especially potassium sulfate $(\mathrm{K})$, urea ammonium super phosphate (NP), and nitro phosphate potash mixed (NPK) fertilizers with high concentrations of ${ }^{226} \mathrm{Ra},{ }^{232} \mathrm{Th}$, and ${ }^{40} \mathrm{~K}$ radioisotopes.

\section{Conclusions}

The activity concentrations of naturally occurring radioactive nuclides in virgin and agricultural soil of the studied area were measured using gamma spectrometry. The obtained data revealed that the activity concentrations of ${ }^{226} \mathrm{Ra},{ }^{232} \mathrm{Th}$, and ${ }^{40} \mathrm{~K}$ in agricultural soil were higher than those in virgin by factors of $(0.5-23.0) \%$, (0.2-16.9)\%, and (0-13.4)\%, resepectivily. The use of chemical fertilizers in the agricultural fields to enhance the crop yield causes an increase in the activity concentrations of natural radioactive nuclides, as well as the exposure of the farmers working in the agricultural fields, especially in those fields using potassium sulfate $(\mathrm{K})$, urea ammonium super phosphate (NP), and nitro phosphate potash mixed (NPK) fertilizers with high concentrations of ${ }^{226} \mathrm{Ra},{ }^{232} \mathrm{Th}$, and ${ }^{40} \mathrm{~K}$. The values of the activity concentrations of naturally occurring radionuclides in the virgin and the fertilized soil of the studied area were within the world average as proposed by UNSCEAR.

The calculated values of the radiological hazard parameters (radium equivalent activity, the external hazard index, external absorbed gamma dose rates, outdoor annual effective dose, and excess lifetime cancer risk) for virgin and agricultural soil samples were in general also increased and modified by the effect of fertilizer use. However, in both virgin and fertilized soils, the level of these parameters was below the international dose limit in the soil as proposed by UNSCEAR and OECD. The conclusion of this work is that these farms and their soils and subsequently their products pose no health hazard for the population in terms of radiation impact.

\section{Acknowledgements}

The authors acknowledge the Directorate of Agriculture Research-Erbil of the Ministry of Agriculture, the Center of Scientific Research Salahaddin University, Erbil, and the Director of Laboratory of Nuclear Radioactivity Testing and 
Monitoring - Koya University, for their help in conducting this research.

\section{References}

1. CHIBOWSKI S., GŁADYSZ A. Examination of Radioactive Contamination in the Soil-Plant System and Their Transfer to Selected Animal Tissues. Polish Journal of Environmental Studies, 8 (1), 19, 1999.

2. KANT K., UPADHYAY S.B., SONKAWADE R.G., CHAKARVARTI S.K. Radiological risk assessment of use of phosphate fertilizers in soil. Iranian Journal of Radiation Research, 4 (2), 63, 2006.

3. ALSHAHRI F., EL-TAHER A. Investigation of Natural Radioactivity Levels and Evaluation of Radiation Hazards in Residential-Area Soil Near a Ras Tanura Refinery, Saudi Arbia. Polish Journal of Environmental Studies, 28 (1), 25, 2019.

4. RADHAKRISHNA A.P., SOMASHEKARAPPA H.M., NARAYANA Y., SIDDAPPA K. A new natural background radiation area on the southwest coast of India. Health Physics, 65 (4), 390, 1993.

5. ALZUBAIDI G., HAMID F.B.S., ABDUL RAHMAN I. Assessment of Natural Radioactivity Levels and Radiation Hazards in Agricultural and Virgin Soil in the State of Kedah, North of Malaysia. Scientific World Journal, 2016. 2016 .

6. ALHARBI A., EL-TAHER A. A study on transfer factors of radionuclides from soil to plant. Life Science Journal, 10 (2), 532, 2013.

7. ALHARBI W.R. Natural Radioactivity and Dose Assessment for Brands of Chemical and Organic Fertilizers Used in Saudi Arabia. Journal of Modern Physics, 2013 (3), 344, 2013.

8. BOUKHENFOUF W., BOUCENNA A. The radioactivity measurements in soils and fertilizers using gamma spectrometry technique. Journal of Environmental Radioactivity, 102 (4), 336, 2011.

9. ABBADY A., EL-ARABI A.M., ABBADY A.G.E., TAHA S. Gamma-ray measurements of natural radioactivity in cultivated and reclaimed soil, Upper Egypt. In International Conference on Radioecology and Environmental Radioactivity, 15, 2008.

10. AHMED N.K., EL-ARABI A.G.M. Natural radioactivity in farm soil and phosphate fertilizer and its environmental implications in Qena governorate, Upper Egypt. Journal of Environmental Radioactivity, 84 (1), 51, 2005.

11. AZEEZ H.H., AHMAD S.T., HANNA H. Assessment of radioactivity levels and radiological-hazard indices in plant fertilizers used in Iraqi Kurdistan Region. Journal of Radioanalytical and Nuclear Chemistry, 317 (3), 1273. 2018.

12. RIGHI S., LUCIALLI P., BRUZZI L. Health and environmental impacts of a fertilizer plant - Part I: Assessment of radioactive pollution. Journal of Environmental Radioactivity, 82 (2), 167, 2005.

13. GUILLEN J., BAEZA A., SALAS A., MUÑOZ-MUÑOZ J.G., MUÑOZ-SERRANO A. Factors Influencing the Soil to Plant Transfer of Radiocaesium. Impact of Cesium on Plants and the Environment, 19, 2017.

14. HAMBY D.M., TYNYBEKOV A.K. Uranium, thorium, and potassium in soils along the shore of Lake Issyk-Kyol in the Kyrghyz Republic. Environmental monitoring and assessment, 73 (2), 101, 2002.
15. HUSSAIN R.O., HUSSAIN H.H. Investigation the natural radioactivity in local and imported chemical fertilizers. Brazilian Archives of Biology and Technology, 54 (4), 777, 2011.

16. AHMAD S.T. High purity Germanium Koya4039 Gamma detection system. ICEEAS-2016-Proceedings-Book., 2016, 268, 2016.

17. GILMORE G.R. Practical gamma-ray spectrometry. John Wiley \& Sons $\left(2^{\text {nd }}\right.$ ed.). Warrington: John Wiley \& Sons. 2008.

18. SROOR A., AFIFI S.Y., ABDEL-HALEEM A.S., SALMAN A.B., ABDEL-SAMMAD M. Environmental pollutant isotope measurements and natural radioactivity assessment for North Tushki area, south western desert, Egypt. Applied radiation and isotopes, 57 (3), 427, 2002.

19. SAMAD M.A., ALI M.I., PAUL D., ISLAM S. M.A. Assessment of Radioactivity in the Wastes Generated from the Diammonium Phosphate (DAP) Fertilizer Factory, chittagong, Bangladesh. Jahangirnagar University Environmental Bulletin, 1, 15, 2012.

20. OECD. Exposure to radiation from the natural radioactivity in building materials. Report by an NEA group of experts. Paris. Retrieved from https://www.oecdnea.org/rp/reports/1979/exposure-to-radiation-1979.pdf 1979.

21. ALAAMER A.S. Assessment of human exposures to natural sources of radiation in soil of riyadh, Saudi Arabia. Turkish Journal of Engineering and Environmental Sciences, 32 (4), 229, 2008.

22. UNSCEAR. Sources and effects of ionizing radiation. United Nations Publications (Vol. 1). New York: Scientific Committee on the Effects of Atomic Radiation. 2000

23. AL-BAKHAT Y.M.Z., AL-ANI N.H.K., MOHAMMED B.F., AMEEN N.H., JABR Z.A., HAMMID S.H. Measurement of Radon Activity in Soil Gas and the Geogenic Radon Potential Mapping Using RAD7 at Al-Tuwaitha Nuclear Site and the Surrounding Areas, 3 (3), 29, 2017.

24. UNSCEAR. Sources and Effects of Ionising Radiation. United Nations Publications. New York. 1993.

25. HAMEED P.S., PILLAI G.S., MATHIYARASU R. A study on the impact of phosphate fertilizers on the radioactivity profile of cultivated soils in Srirangam (Tamil $\mathrm{Nadu}$, India). Journal of Radiation Research and Applied Sciences, 7 (4), 463, 2014.

26. QURESHI A.A., TARIQ S., DIN K.U., MANZOOR S., CALLIGARIS C., ABDUL WAHEED Evaluation of excessive lifetime cancer risk due to natural radioactivity in the rivers sediments of Northern Pakistan. Journal of Radiation Research and Applied Sciences, 7 (4), 438, 2014.

27. EL-BAHI S.M., SROOR A., MOHAMED G.Y., ELGENDY N.S. Radiological impact of natural radioactivity in Egyptian phosphate rocks, phosphogypsum and phosphate fertilizers. Applied Radiation and Isotopes, 123 (September 2016), 121, 2017.

28. International Commission on Radiological Protection. Recommendations of the International Commission on Radiological Protection. Elsevier, Amsterdam: ICRP;1991. ICRP publication 60, 1991.

29. HAMEED P.S., PILLAI G.S., MATHIYARASU R. A study on the impact of phosphate fertilizers on the radioactivity profile of cultivated soils in Srirangam (Tamil $\mathrm{Nadu}$, India). Journal of Radiation Research and Applied Sciences, 7 (4), 463, 2014. 
30. BECEGATO V.A., FERREIRA F.J.F., MACHADO W.C.P. Concentration of radioactive elements (U, Th and K) derived from phosphatic fertilizers in cultivated soils. Brazilian Archives of Biology and Technology, 51 (6), $1255,2008$.

31. GUIDOTTI L., CARINI F., ROSSI R., GATTI M., CENCI R.M., BEONE G.M. Gamma-spectrometric measurement of radioactivity in agricultural soils of the Lombardia region, northern Italy. Journal of Environmental Radioactivity, 142, 36, 2015.

32. SERVITZOGLOU N.G., STOULOS S., KATSANTONIS D., PAPAGEORGIOU M., SIOUNTAS A. Natural Radioactivity studies of Phosphate Fertilizers Applied on Greek Farm Soils used for Wheat Cultivation. Radiation Protection Dosimetry, 2018 (February), 1, 2018.

33. ABU-KHADRA S.A., EISSA H.S. Natural Radionuclides in Different plants, Together with Their Corresponding Soils in Egypt at Inshas Region and the Area Nearby. IX Radiation Physics \& Protection Conference, (November), $15,2008$.

34. AKHTAR N., TUFAIL M., HUSSAIN M.Y., AKRAM M. Primordial radionuclides contamination level in fertilized farms soils of Faisalabad-Pakistan. Soil and Environment, 30 (1), 88, 2011.
35. YANG B., ZHOU Q., ZHANG J., LI Z., LI W., TUO F. Assessment of radioactivity level and associated radiation exposure in topsoil from eastern region of Shangrao Prefecture, China. Journal of Radioanalytical and Nuclear Chemistry, 319 (1), 297, 2019.

36. TURHAN Ş., GÖREN E., UĞUR F.A., KARATAŞLL M., YEĞINGIL Z. Study of the radioactivity in environmental soil samples from Eastern Anatolia Region of Turkey. Radiochimica Acta, 106 (2), 161, 2018.

37. CENGIZ G.B. Transfer factors of ${ }^{226} \mathrm{Ra},{ }^{232} \mathrm{Th}$ and ${ }^{40} \mathrm{~K}$ from soil to pasture - grass in the northeastern of Turkey. Journal of Radioanalytical and Nuclear Chemistry, 319 (1), 83, 2019.

38. FATHIVAND A.A., MORADI M., KASHIAN S. Radiological impact of phosphate fertilizers on the agricultural areas in Iran. Radiation Protection and Environment, 37 (1), 2, 2014.

39. NAJAM L.A., YOUNIS S.A., KITHAH F.H. Natural Radioactivity in Soil Samples in Nineveh Province and the Associated Radiation Hazards. International Journal of Physics, 3 (3), 126, 2015. 